\title{
Challenges and Trends for the Incorporation of Big Data in the Accounting Profession: From the Traditional Approach to the Future Professional Accountant
}

\author{
Associate Professor Adrian GROȘANU, PhD, Associate Professor Melinda-Timea FÜLÖP, PhD, \\ Associate Professor George-Silviu CORDOȘ, PhD, Gabriel RAITA, PhD student \\ "Babeș-Bolyai" University, Cluj-Napoca, Romania
}

\begin{abstract}
In the present article we analyse the usage of the Big Data techniques in the accounting profession, the authors' findings revealing that this system is not as widely used by professional accountants as in other related fields. Firstly, we present modern data techniques to promote the understanding of their application potential highlighting the need for the accounting profession to head towards Big Data and financial review methods. The modern engagements in the accounting profession often imply the review of the clients using Big Data in order to remain competitive and relevant in the current business environment. Thus, the theoretical part is supplemented by a case study regarding the level of knowledge concerning the Big Data concept among professional accountants. In a Big Data environment, the professional accountant has the potential to perform more advanced projection analysis. Lastly, we present a series of conclusions that we hope will contribute to the literature, because professional accountants are interested in this field.
\end{abstract}

Key terms: Big Data, digital era, artificial intelligence, accounting profession, professional accountant JEL Classification: 033, M41

To cite this article: Adrian Groșanu, Melinda-Timea Fülöp, George-Silviu Cordoș, Gabriel Raita, Challenges and Trends for the Incorporation of Big Data in the Accounting Profession: From the Traditional Approach to the Future Professional Accountant, CECCAR Business Review, № 12/2020, pp. 64-72, DOI: http://dx.doi.org/10.37945/cbr.2020.12.08

\section{Introduction}

Today, more and more researchers are turning their attention to the impact of using Big Data among customers (Appelbaumet et al., 2017) and not only, but also to the use of this system by accounting and audit firms (Vasarhelyi et al., 2015; Zhang et al., 2015b). Thus, our paper is focused on the precious opportunity offered by modern-day techniques such Big Data in the accounting profession.

In the digital era, it is time to reconsider how we approach the opportunities and risks of our businesses. The speed with which data is circulating in today's IT environment brings a number of advantages as well as a number of disadvantages, therefore, since much of the information is very valuable, it is important to detect and act immediately when irregularities occur.

In the digital and internet age, more and more customers are focusing on artificial intelligence and integrated cloud systems, the Internet of Things and external data sources, such as social media. The high volume of information and the variety of information that clients work with in their business presents a growing demand for Big Data (Cukier \& Mayer-Schoenberger, 2013). The information that Big Data can store and filter is of different 
types and sizes that the accounting profession probably wasn't aware of often (Warren et al., 2015). Big Data researchers and especially accountants believe that Big Data should provide accountants with the ability to perform complex analyzes and predictions by continuing the activity based on the information stored and filtered by the Big Data system (Holsapple et al., 2014; Lee et al., 2014; Delen \& Demirkan, 2013).

Moreover, researchers in the Big Data domain (Atzori et al., 2010; Domingos, 2012; Vasarhelyi et al.; 2015, Dai \& Vasarhelyi, 2016) believe that these environments will progressively connect with corporate systems.

The Big Data solution is a new opportunity for today's businesses. Big Data offers the ability to store and transfer business information and files. Big Data is an artificial intelligence solution used in many fields, so most operating systems such as Linux, UNIX and Windows (LUW) already contain high value data and drive critical transaction processes for different missions. Through Big Data we can monitor data, fast-moving operations from most sources, we can also manage to act immediately to optimize performance, protect information and, especially, prevent fraud.

Furthermore, Big Data manages to analyze, correlate, aggregate, filter and query large volumes of fastmoving data from multiple sources simultaneously, to support correct decision-making with immediate viewing (see Figure 1).

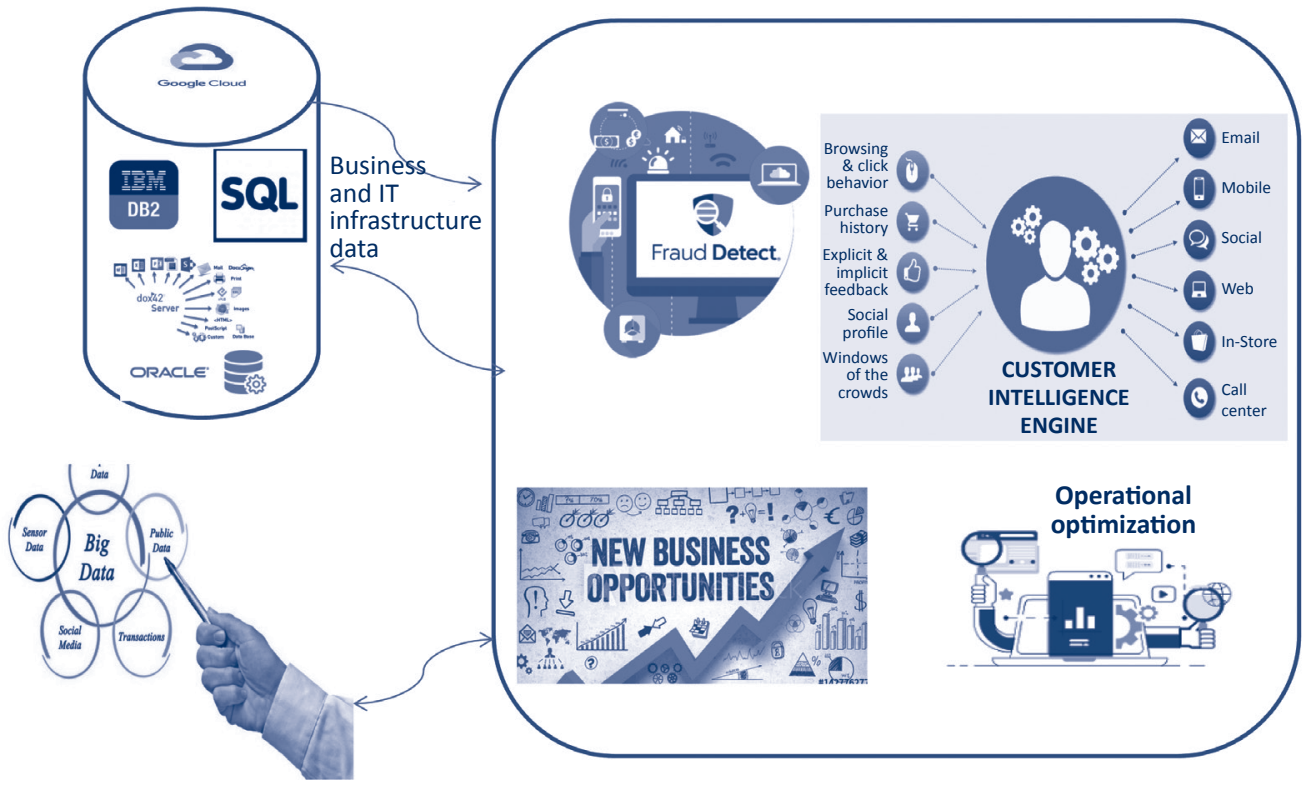

Figure 1. Optimize performance, protect sensitive information and prevent fraud with Big Data

Source: Projection of authors.

\section{Big Data process}

Before we look at the implications of the Big Data system on the accounting profession, we believe that we need to make a brief incursion into what Big Data means, because accountants need to be familiar with this notion (Appelbaum et al., 2017). As an introduction to the notion of Big Data, we consider it is necessary to provide a background to present the major available Big Data processes and key information required in order to establish which ones are appropriate in a given situation.

The term of Big Data has evolved to account for the fast expanding amounts of digital information systems that are being generated, the hard work to make that information analysable and the actual use of that data as a capital to improve efficiency, create and make possible innovations and improve decision making. 
Gartner defined Big Data as high volume, velocity and variety information assets that demand cost-effective, innovative forms of information processing for enhanced insight and decision making (http://www.gartner. com/it-glossary/big-data/).

Enterprise IT linking systems via typical extract, transform, load (ETL) processing (see step 1 of Figure 2) have lead for many years to controlled and repeatable examination. In step 1, the big business determines the questions to be asked and the IT collects and structures the data required to respond to individuals' questions.

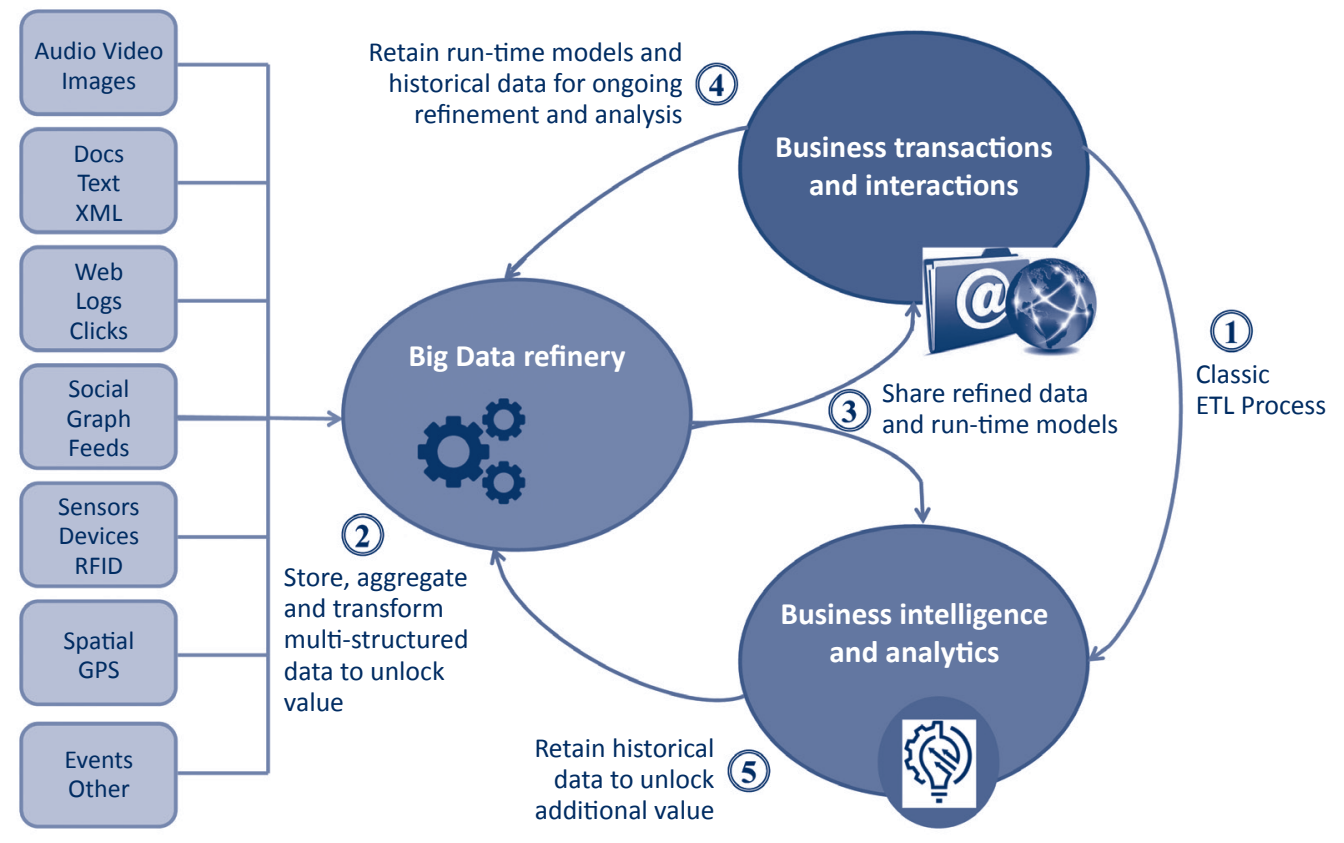

Figure 2. Maximizing the value of data

Source: Kumar \& Rohit, 2013.

Step 2 presents the restructuring and storage of data, as well as its transformation into a usable format that constitutes a business perspective in fraud detection and prevention. Moving on to the prevention of errors and frauds, in case of data storage, accountants and auditors could collaborate with IT and develop a significance threshold for the security alerts delivered by the IT system. Data filtering and refining by means of IT techniques can significantly contribute to reducing the time and workload and, furthermore, to the prevention of human error and fraud.

Step 3 shows the merging of the refined data with the supply of transactions, business interactions, as well as the business information. Complex examinations and calculations of key parameters can be performed in the refinery and downstream flow to fuel run-time models powering big business applications, with the aspiration of more precisely targeting clientele with the greatest and mainly pertinent offers, for example.

As data filtering and refining is a complex process and a good way of storing large volumes of data over a long period of time, it is very important that we also have a control, respectively, of the feedback presented it in steps 4 and 5 . By storing long-term data, we can quickly and easily view information and perform different analyses to optimize business.

The future of the Big Data system in the accounting field is represented by the implementation of new techniques and processes of feeding classical information through artificial business intelligence. 


\section{Big Data - the future of the accounting profession}

These new technologies and storage media that are revolutionizing today's market can substantially change the environment and accounting and auditing practices. Nowadays it is not enough to be a good accountant or a good auditor, nowadays you must be prepared to face different media and information technologies that dictate the business trend.

While business processes are facing the progressive implementation of the Big Data system (Vasarhelyi et al., 2015), accountants and auditors are just beginning to innovate and integrate the new possibilities and threats of the new technology (Acito \& Khatri, 2014; Alles, 2015; Brown-Liburd \& Vasarhelyi, 2015; Cao et al., 2015; Earley, 2015; Griffin \& Wright, 2015; Krahel \& Titera, 2015; Werner \& Gehrke, 2015; Zhang et al., 2015a).

Earley (2015) recognizes that Big Data might be a game-changer for the audit mission. Schneider et al. (2015) predicts that data examination will considerably modify the way of the auditing profession. Furthermore, Griffin and Wright (2015) refer to the slow engagement in Big Data as the highest probable risk in the field and calls for it to be used more extensively in practice, education, and research.

At a theoretical or normative stage, it seems rational that accountants and auditors will integrate Big Data into future activities (Moffitt \& Vasarhelyi, 2013; Cao et al., 2015; Vasarhelyi et al., 2015; Warren et al., 2015).

One of the key factors that has contributed to the development and emergence of new trends is the speed with which the IT system has developed or in other words the internet age. The first steps in the development of IT systems and their application in the accounting field were the ERP systems (enterprise resource planning).

ERP system became a necessity due to the competitive force on the national and international market once this system became viral and irreplaceable in the accounting field. Therefore, we believe that Big Data will have a similar development and adoption similarly to the ERP system among accountants and auditors, due to the fact that more and more business customers are using this system. Thus, accountants will meet the market needs and requirements and will implement the Big Data in their work process. Accountants will embrace Big Data in their accountancy work in the future, as exogenous market forces compel them to do so.

The IT environment continues to evolve and become more complex, and the timing and the sources of information are becoming more and more important and complex (Appelbaum, 2016; Brown-Liburd \& Vasarhelyi, 2015; Warren et al., 2015; Nearon, 2005), but all these deficiencies can be overcome through the use of artificial intelligence and IT systems. However, the quality and verifiability of these non-quantitative external sources becomes even more important in the risk assessment process (Appelbaum, 2016).

Researchers in the field of accounting are also concerned about the issue regarding risk assessment, which differs in electronic format from the classic paper sources. Many of the attributes that are positive characteristics for paper evidence present challenges for electronic evidence (Appelbaum, 2016; Nearon, 2005). Alles (2015) argues that, in order to preserve credibility, accountants need to be familiar with the practices of their customers. In addition, as data-driven approaches turn out to be more general, accounting-clients will probably perceive the use of Big Data techniques as ordinary.

As a conclusion, Krahel \& Titera (2015) underline that the accounting and auditing regulation and standards have not set the scientific changes aside and continue to highlight presentation, aggregation and sampling. As a result, many researchers stress the need to change the accounting and auditing standards, and further encourage the importance of introducing the notion of Big Data at the academic level among students to prepare them for future work (Moffitt \& Vasarhelyi, 2013; Vasarhelyi et al., 2015; Appelbaum et al., 2017). 


\section{Practical study}

Digitalization is changing the accounting profession and other organizations more fundamentally than the business world has ever experienced before. This change will also occur in the finance and accounting departments of a company. But what does the future of accounting look like?

As part of our analysis on the subject of digital accounting, we developed a questionnaire for accountants. For this purpose, we sent the questionnaire to 100 accountants in order to spot their preferences and trends regarding the new challenges in the field of IT support. We have received 68 of the questionnaires back, but not all of them were fully completed, so we excluded those and analyzed only 56 fully completed questionnaires. As a result of collecting these answers, we eliminated the answers of the companies that did not fully complete the questionnaire.

A first element that we wanted to find out from the surveyed accountants was if they use IT techniques in their activity. Accountants had the option to choose more answers, and we could see that most of them surveyed use basic IT programs without resorting to complex software.

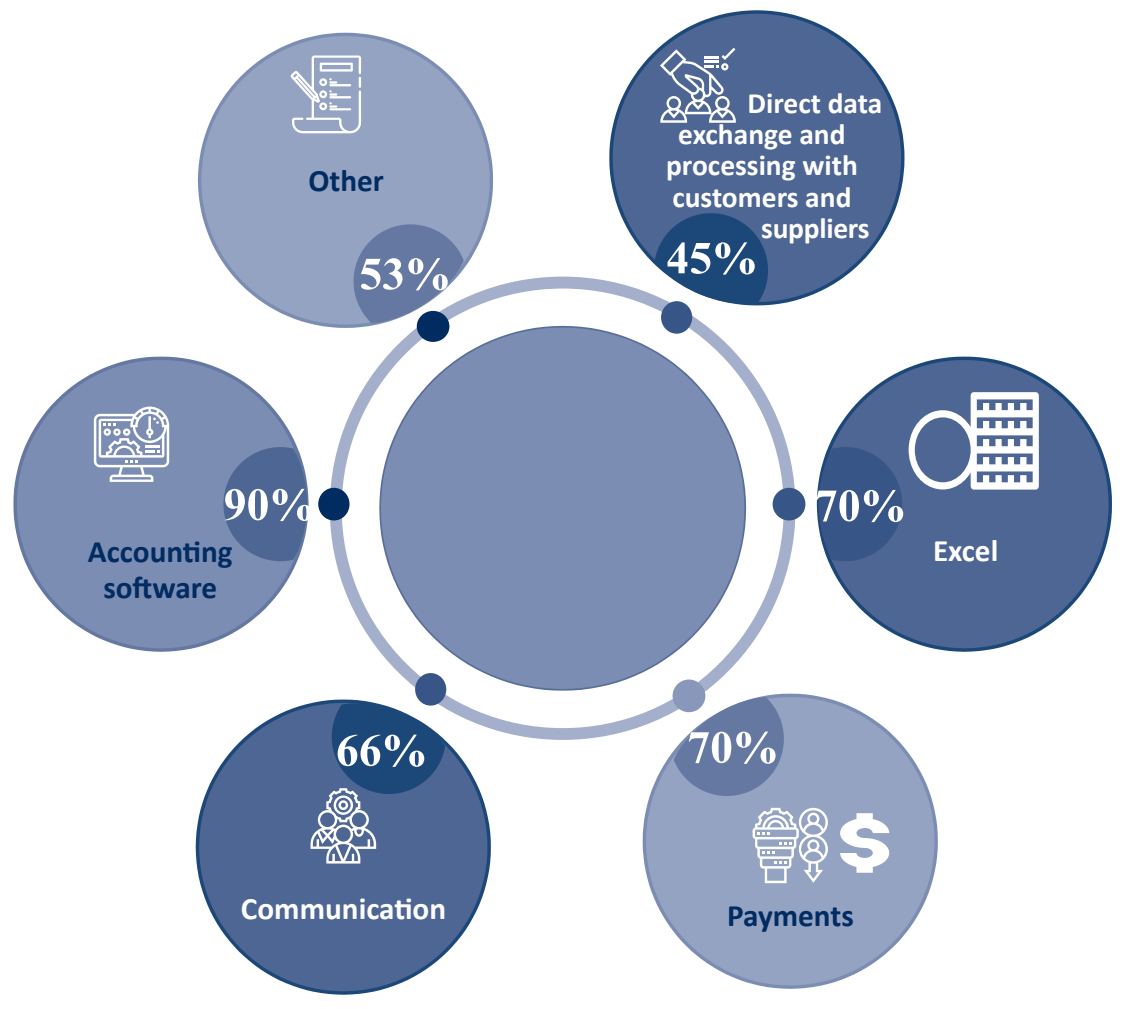

Figure 3. IT techniques used by professional accountants

Source: Projection of authors.

All the accountants that took part in our study called for IT support but none of the respondents used Big Data. They confirmed that they are using Cloud, Dropbox and other storage media.

In many companies, the digitization of finance and accounting is progressing quickly on average, according to their own assessment. They mentioned that the artificial intelligence is coming along slowly but surely, because this is the new trend in the IT branch. The artificial intelligence megatrend is slowly making its way into accounting and because the use of artificial intelligence requires some know-how in the field of IT, it is not enough to just have good accounting knowledge, the new accountants or auditors need to also have very good IT knowledge. 
Although $85 \%$ of the accountants surveyed are currently not using artificial intelligence, only $15 \%$ of the accountants are already using artificial intelligence-supported systems and a further $30 \%$ plan to use such systems.

The digital future of the accounting profession is a must, because the suppliers use these types of systems. The use of new accounting technologies is expected above all in the areas of document recognition, data exchange, payment transactions, communication, replacement of Excel, text recognition and other activities. $90 \%$ of those surveyed hoped that this would result in a stronger focus on content-related work, in contrast to routine activities.

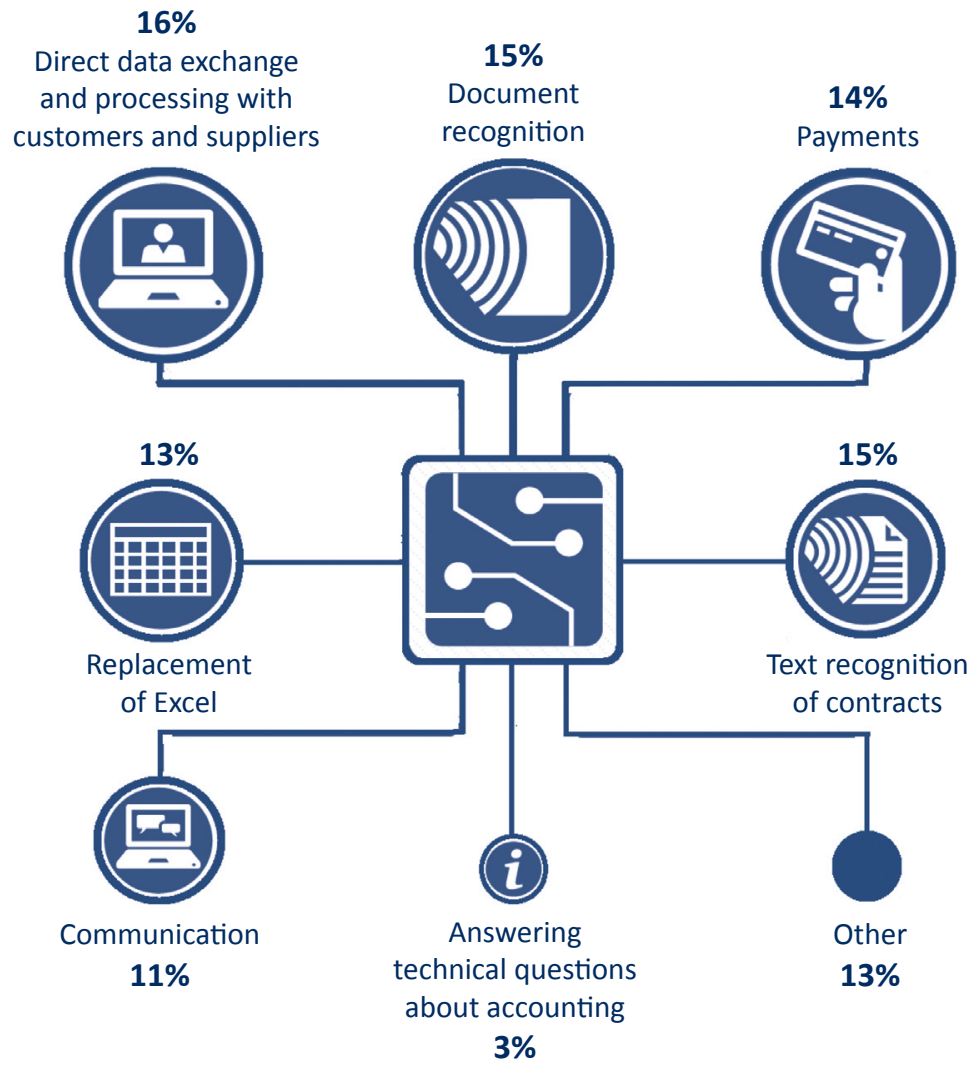

Figure 4. Future digital advances in accounting

Source: Projection of authors.

The increased use of technology is often accompanied by the fear that people can be replaced by technology. Experts do not see this danger present in accounting and auditing. Only $10 \%$ of those surveyed expect a significant reduction in the number of employees in accounting due to technology, because many decisions are based on the professional judgment and this is not easily achieved by the new technology, there must be people behind these decisions.

The majority of the accountants surveyed (94\%) believe that accountancy will change massively in the coming years due to the technological change. Experts are expecting significant changes, especially when it comes to checking IT systems and historical financial information.

Therefore, most of the accountants that have completed the questionnaire stress the importance of introducing the notion of Big Data at the academic level among the students to prepare them for their future job and those who have already passed this stage consider that an initiation in the field of IT, especially with 
regard to Big Data, is strictly necessary, because a good accountant is not necessarily also a good IT specialist and a good IT specialist is not necessarily also a good accountant, although the age that we live in demands more and more computer knowledge along with professional knowledge.

\section{Conclusions}

Big Data becomes an indispensable resource for many organizations and has the potential to be an extremely valuable resource for professional accountants. But this presumption should not be taken as such without further investigation with potential skepticism.

Will the accountants not use Big Data unless the failure to adopt Big Data is perceived by the accounting profession as a serious threat? The answer to this question is still a challenge, especially in the field of accounting because most, or almost all, accounting entities avoid using Big Data.

In order to emphasize the importance and role of Big Data in the accounting profession, we will present, based on our research, the main advantages and disadvantages that Big Data can bring through its implementation by professional accountants:

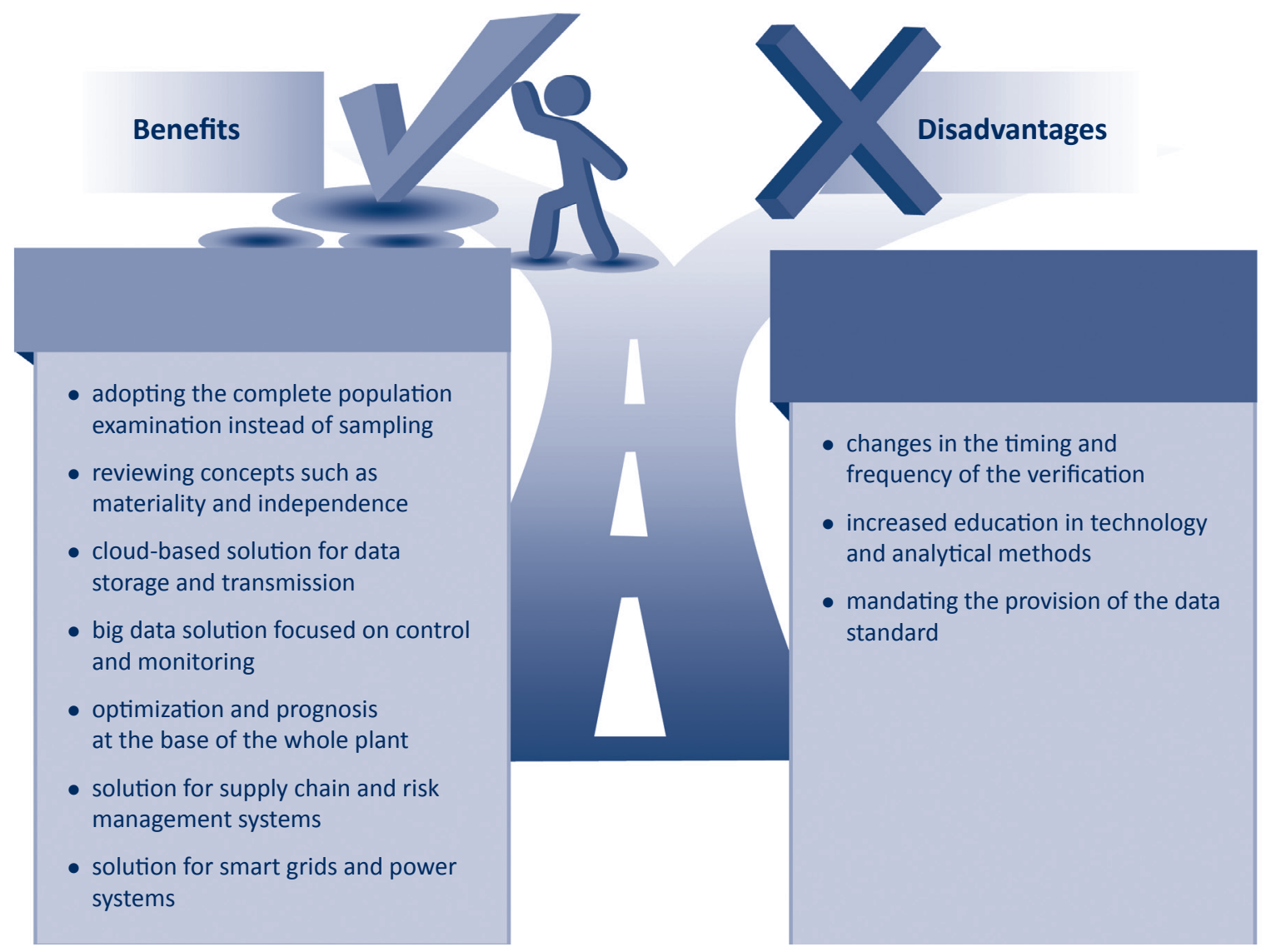

Source: Projection of authors.

Monitoring the flows within a business is particularly important, therefore Big Data supports this activity through real-time received alerts from smart meters, database events and log data, inconsistency among consumption and billing, changes in consumption patterns compared to historical levels and processes linked with investigating problematic service and security levels. Then, by integrating these several streams in a technique that allows real-time association and benchmarking, businesses offer staff the tools to recognize fraud earlier on, protecting your infrastructure as well as your revenue. 
Accountants have made enormous strides in the last years, but they have apparently not kept up with the real-time economy. A number of approaches and accounting processes that were precious in the past appear out-of-date now in the digital era. The evolution of the accounting profession has reached a dangerous position, whereby the accountants can also lead in the endorsement and implementation of the future accountancy profession or continue to hold on to the more traditional paradigm in a certain way. Prospective approaches to the accounting profession would probably require accountants, regulatory authorities, and standard-makers to make significant adjustments. Thus, accountants should acquire considerable technical, investigative, and analytical skills that are not at this time part of the most conventional university accounting programs.

Being a subject that pushes the interdisciplinary boundaries, Big Data has the potential to attract increasing attention of both the academic and professional communities so it would be a topic for helpful future research.

\section{References}

1. Acito, F., Khatri, V. (2014), Business Analytics: Why Now and What Next?, Business Horizons, Vol. 57, No. 5, pp. 565-570.

2. Alles, M.G. (2015), Drivers of the Use and Facilitators and Obstacles of the Evolution of Big Data by the Audit Profession, Accounting Horizons, Vol. 29, No. 2, pp. 439-449.

3. Appelbaum, D. (2016), Securing Big Data Provenance for Auditors: The Big Data Provenance Black Box as Reliable Evidence, Journal of Emerging Technologies in Accounting, Vol. 13, No. 1, pp. 17-36.

4. Appelbaum, D., Kogan, A., Vasarhelyi, M.A. (2017), Big Data and Analytics in the Modern Audit Engagement: Research Needs, Auditing: A Journal of Practice \& Theory, Vol. 36, No. 4, pp. 1-27.

5. Atzori, L., lera, A., Morabito, G. (2010), The Internet of Things: A Survey, Computer Networks, Vol. 54, No. 15.

6. Brown-Liburd, H., Issa, H., Lombardi, D. (2015), Behavioral Implications of Big Data's Impact on Audit Judgment and Decision Making and Future Research Directions, Accounting Horizons, Vol. 29, No. 2, pp. 451-468.

7. Brown-Liburd, H., Vasarhelyi, M.A. (2015), Big Data and Audit Evidence, Journal of Emerging Technologies in Accounting, Vol. 12, No. 1, pp. 1-16.

8. Cao, M., Chychyla, R., Stewart, T. (2015), Big Data Analytics in Financial Statement Audits, Accounting Horizons, Vol. 29, No. 2, pp. 423-429.

9. Csubák, D., Szücs, K., Vörös, P., Kiss, A. (2016), Big Data Testbed for Network Attack Detection, Acta Polytechnica Hungarica, Vol. 13, No. 2, pp. 47-57.

10. Cukier, K., Mayer-Schoenberger, V. (2013), Rise of Big Data. How It's Changing the Way We Think About the World, Foreign Affairs, Vol. 92, No. 3, pp. 28-40.

11. Dai, J., Vasarhelyi, M.A. (2016), Imagineering Audit 4.0, Journal of Emerging Technologies in Accounting, Vol. 13, No. 1, pp. 1-15.

12. Delen, D., Demirkan, H. (2013), Data, Information and Analytics as Services, Decision Support Systems, Vol. 55, No. 1, pp. 359-363.

13. Dohrer, R., Vasarhelyi, M.A., McCollough, P. (2015), Audit Data Analytics. Presentation Delivered to the IAASB.

14. Domingos, P. (2012), A Few Useful Things to Know About Machine Learning, Communications of the ACM, Vol. 55, No. 10, pp. 78-87.

15. Earley, C.E. (2015), Data Analytics in Auditing: Opportunities and Challenges, Business Horizons, Vol. 58 , No. 5, pp. 493-500. 
16. Gepp, A., Linnenluecke, M.K., O’Neill, T.J., Smith, T. (2018), Big Data Techniques in Auditing Research and Practice: Current Trends and Future Opportunities, Journal of Accounting Literature, No. 40, pp. 102-115.

17. Griffin, P.A., Wright, A.M. (2015), Introduction: Commentaries on Big Data's Importance for Accounting and Auditing, Accounting Horizons, Vol. 29, No. 2, pp. 377-379.

18. Holsapple, C., Lee-Post, A., Pakath, R. (2014), A Unified Foundation for Business Analytics, Decision Support Systems, No. 64, pp. 130-141.

19. Jocic, M., Pap, E., Szakál, A., Obradovic, D., Konjovic, Z. (2017), Managing Big Data Using Fuzzy Sets by Directed Graph Node Similarity, Acta Polytechnica Hungarica, Vol. 14, No. 2, pp. 183-200.

20. Krahel, J.P., Titera, W.R. (2015), Consequences of Big Data and Formalization on Accounting and Auditing Standards, Accounting Horizons, Vol. 29, No. 2, pp. 409-422.

21. Kumar, S., Rohit, B. (2013), What Is Big Data and What Does It Have to Do With IT Audit?, ISACA Journal, Vol. 3, pp. 1-3.

22. Lee, M., Cho, M., Gim, J., Jeong, D.H., Jung, H. (2014), Prescriptive Analytics System for Scholar Research Performance Enhancement, in HCl International 2014 - Posters' Extended Abstracts, Part I, Springer International Publishing, New York, pp. 186-190.

23. Moffitt, K.C., Vasarhelyi, M.A. (2013), AIS in an Age of Big Data, Journal of Information Systems, Vol. 27, No. 2, pp. 1-19.

24. Nearon, B.H. (2005), Foundations in Auditing and Digital Evidence, The CPA Journal, Vol. 7, No. 1.

25. Schneider, G.P., Dai, J., Janvrin, D.J., Ajayi, K., Raschke, R.L. (2015), Infer, Predict, and Assure: Accounting Opportunities in Data Analytics, Accounting Horizons, Vol. 29, No. 3, pp. 719-742.

26. Vasarhelyi, M.A., Kogan, A., Tuttle, B.M. (2015), Big Data in Accounting: An Overview, Accounting Horizons, Vol. 29, No. 2, pp. 381-396.

27. Warren, J.D., Moffitt, K.C., Byrnes, P. (2015), How Big Data Will Change Accounting, Accounting Horizons, Vol. 29, No. 2, pp. 397-407.

28. Werner, M., Gehrke, N. (2015), Multilevel Process Mining for Financial Audits, IEEE Transactions on Services Computing, Vol. 8, No. 6, pp. 820-832.

29. Zhang, J., Yang, X., Appelbaum, D. (2015a), Toward Effective Big Data Analysis in Continuous Auditing, Accounting Horizons, Vol. 29, No. 2, pp. 469-476.

30. Zhang, X., Hu, Y., Xie, K., Zhang, W., Su, L., Liu, M. (2015b), An Evolutionary Trend Reversion Model for Stock Trading Rule Discovery, Knowledge-Based Systems, No. 79, pp. 27-35.

31. http://www.gartner.com/it-glossary/big-data/ 